\title{
Enhancement of very high gravity bioethanol production via fed-batch fermentation using sago hampas as a substrate
}

\author{
Nur Adila Muradi, Dayang Salwani Awang Adeni*, Nurashikin Suhaili \\ Resource Biotechnology Programme, Faculty of Resource Science and Technology, Universiti Malaysia Sarawak, 94300 Kota Samarahan, \\ Sarawak, Malaysia
}

Received 27th February 2020 / Accepted 10th June 2020

\begin{abstract}
Very high gravity (VHG) ethanolic fermentation is a promising technology used for producing bioethanol. However, the technology is often associated with the excessive amount of glucose that is entirely supplied in the beginning of the culture causing the fermentation process to be sluggish and therefore inhibits complete utilisation of glucose. The high concentration of glucose in the fermentation medium also elevates the osmotic pressure, which has a destructive effect on yeast cells. This study aims to enhance the production of VHG bioethanol from sago hampas hydrolysate $(\mathrm{SHH})$ via fed-batch fermentation. The fermentations were performed in a 2-L stirred tank bioreactor. Batch fermentation was conducted as a control. Our results showed that the maximum yeast cell concentration achieved was significantly improved by 1.5 -fold when the fermentation was carried out in fed-batch mode. The ethanol yield attained in the fed-batch culture represents an enhancement of $22 \%$ over that achieved in the batch culture. Moreover, the ethanol productivity achieved in the fed-batch culture was found to be increased by 1.8 times in comparison to the productivity attained in the batch culture. In general, this work provides useful insights into promising techniques for enhancing VHG fermentations in the stirred tank bioreactor employing agricultural residues as feedstocks.
\end{abstract}

Keywords: Ethanol, fed-batch system, osmotic pressure, substrate inhibition, very high gravity (VHG) fermentation, yeast

\section{INTRODUCTION}

Bioethanol has emerged as a sustainable and ecofriendly alternative to the conventional fossil fuel that poses major environmental problems. Currently, there is an increasing interest to exploit lignocellulosic waste as feedstocks for producing bioethanol. Apart from being cheap feedstocks, the use of lignocellulosic waste for bioproduction may also overcome the disposal problem that may otherwise be caused by the bulk dumping of the waste to the environment (Gutierrez-Rivera et al., 2012; Ishola \& Taherzadeh, 2014; Vincent et al., 2014). Lignocellulosic waste generally has high content of starch and cellulosic components, which can be utilised to produce fermentable sugars and bioethanol (Janggu \& Bujang, 2009; Linggang et al., 2012; Awg-Adeni et al., 2013; Jenol et al., 2014).

One of the potential lignocellulosic waste is sago hampas, which is a side product of the sago extraction process. Every year, Sarawak exports about 44,000 tonnes of sago starch mainly to Peninsular Malaysia, Japan and other countries (Awang-Adeni et al., 2010). For every tonne of starch produced, one tonne of sago hampas are

*Author for correspondence: Dayang Salwani Awang Adeni, Resource Biotechnology Programme, Faculty of Resource Science and Technology, Universiti Malaysia Sarawak, 94300 Kota Samarahan, Sarawak, Malaysia. Email-adsalwa@unimas.my 
released into the river (Bujang et al., 1996). It is estimated that at least 40 tonnes of sago hampas are produced daily in Sarawak. Currently, there is no proper way to treat sago hampas, hence most of them are disposed to the river causing severe environmental pollution. Sago hampas on a dry basis has 58\% starch apart from other lignocellulosic components (Linggang et al., 2012). Our previous works have highlighted the feasibility of using sago hampas as a substrate for bioethanol production (Awang-Adeni et al., 2013; Mohammad et al., 2020). The remaining challenge in using sago hampas as a feedstock for bioethanol production, however, lies in the technique used to enhance the productivity of bioethanol fermentation.

Very high gravity (VHG) fermentation is a promising technology for producing bioethanol using high concentration of sugar $(>250 \mathrm{~g} / \mathrm{L})$ at the low expense of water and energy (Ingledew \& Lin, 2011). However, in batch fermentations under VHG conditions, the yeasts undergo various stresses and toxic effects induced by the high concentrations of sugars and ethanol. This has resulted in incomplete fermentation of ethanol (Dodic et al., 2009; Puligundla et al., 2011). In order to lower the drawback of batch VHG fermentation, adoption of a fed-batch system offers an advantage whereby the system can control the feeding rate of the fermentation medium. Thus, it has the potential to minimise the inhibition effects of high concentrations of substrate and ethanol, which exist at the initial and at the end of the ethanol fermentation JoannisCassan et al., 2014). This work aims to investigate the feasibility of fed-batch fermentation system for enhancing the production of bioethanol under VHG condition using sago hampas hydrolysate $(\mathrm{SHH})$ as a main substrate.

\section{MATERIALS AND METHODS}

\section{Raw material preparation}

Sago hampas was collected from Ubom Sago Sdn. Bhd. in Mukah and Herdsen Sago Industry Sdn. Bhd. in Pusa, Sarawak, Malaysia. The hampas was sun-dried for 3-5 days and oven-dried for 1-2 days to completely remove its moisture content. Sago hampas was ground into fine powder with a particle size of approximately $1 \mathrm{~mm}$. The ground sago hampas was then used as a substrate for glucose production via an enzymatic hydrolysis process.

\section{Enzymatic hydrolysis of sago hampas}

A suspension of sago hampas, $7 \%(\mathrm{w} / \mathrm{v})$ was mixed with distilled water. The suspension was then boiled and gelatinised in a steel vessel at 85$90^{\circ} \mathrm{C}$ on a hot plate for 30 minutes. After the gelatinisation process, Liquozymes ${ }^{\circledR}$ SC DS (Novozyme, Denmark) was added into the suspension at a concentration of $2 \mu \mathrm{l} / \mathrm{g}$ and left at the same temperature for another 30 minutes for the liquefaction process to be completed. Throughout the process, the suspension was constantly stirred. Then, the suspension was cooled down to $50-60^{\circ} \mathrm{C}$. Spirizyme ${ }^{\circledR}$ Fuel HS (Novozyme, Denmark), at a concentration of 1 $\mathrm{uL} / \mathrm{g}$ was then added into the suspension for the saccharification stage and left inside the incubator shaker at a temperature of $50-60^{\circ} \mathrm{C}$ for another 56 hours. Three-cycle hydrolysis method as suggested by Awg-Adeni (2015) was performed in this study in order to increase the concentration of glucose in $\mathrm{SHH}$.

\section{Inoculum preparation}

A commonly used instant dry baker's yeast, Saccharomyces cerevisiae was used in this study. Approximately, $1 \mathrm{~g}$ of yeast grains was activated in a sterile Yeast Malt Broth medium and the culture was incubated at $30^{\circ} \mathrm{C}$ overnight. Then, a single loop of the yeast culture was streaked onto Potato Dextrose Agar (PDA). For the batch system, after $24 \mathrm{~h}$, a single colony from the incubated plates was inoculated into sterile 100 $\mathrm{mL}$ inoculum medium containing $100 \mathrm{~g} / \mathrm{L}$ glucose and $5 \mathrm{~g} / \mathrm{L}$ yeast extract. The culture was incubated at $30^{\circ} \mathrm{C}$ for $10-16 \mathrm{~h}$. For the fed-batch system, the inoculum was prepared in two sets with each consisted of $50 \mathrm{~mL}$ inoculum media. The first inoculum was used as a starting culture for $500 \mathrm{~mL}$ fermentation media whereas the second inoculum was added after $24 \mathrm{~h}$ of incubation.

\section{Bioethanol fermentation}

Bioethanol fermentations were carried out in a 2 L stirred tank bioreactor (B Braun, Germany). 
The fermentation medium comprised of $250 \mathrm{~g} / \mathrm{L}$ glucose and $5 \mathrm{~g} / \mathrm{L}$ yeast extract. Th $\mathrm{pH}$ of the fermentation medium was adjusted to 5.5-5.6 using $1 \mathrm{M}$ hydrochloric acid and $1 \mathrm{M}$ sodium hydroxide before sterilisation and it was not controlled during the fermentation process. In the case of batch fermentation, the vessel was initially filled with $1 \mathrm{~L}$ medium and was then sterilised by autoclaving at $121^{\circ} \mathrm{C}$ for 20 minutes. In the case of fed-batch fermentation, the vessel was initially filled with $450 \mathrm{~mL}$ medium before it was autoclaved. Upon cooling to room temperature, an appropriate amount of yeast cells with the final concentration of $7 \times 10^{4}$ cells $/ \mathrm{mL}$ was added to the fermentation medium.

For fed-batch experiment, $50 \mathrm{~mL}$ yeast culture was initially added into the $450 \mathrm{~mL}$ fermentation medium in the bioreactor and the mixture was agitated at $200 \mathrm{rpm}$. After $24 \mathrm{~h}$, another $50 \mathrm{~mL}$ of yeast culture was inoculated into the culture. The two-stage addition of yeasts with the interval of $24 \mathrm{~h}$ was to avoid the decline of yeast count, which normally decreases after 30 $\mathrm{h}$ of incubation. At $30 \mathrm{~h}$, another batch of fresh $450 \mathrm{~mL}$ medium was fed into the fermenter and the agitation speed was increased to $280 \mathrm{rpm}$. The addition of fresh medium was carried out after 30 $\mathrm{h}$ in order to allow the second batch of yeast culture, which was added at $24 \mathrm{~h}$, to grow faster by consuming the residual glucose in the old medium, before consuming the newly added fresh medium. The temperature for both batch and fedbatch cultures was controlled at $30^{\circ} \mathrm{C}$. For batch culture, the agitation speed was maintained at 280 $\mathrm{rpm}$ throughout the incubation. All fermentations were carried out for $72 \mathrm{~h}$ and the sampling was done every $6 \mathrm{~h}$.

\section{Analytical methods Total viable cell count}

The viable yeast cell numbers was determined by methylene blue staining and direct counting using a haemacytometer (Phukoetphim et al., 2017). The formula to calculate the numbers of cells is as follows:

$$
\begin{gathered}
\text { Total no. of } \\
\text { cells } / \mathrm{mL}
\end{gathered}=\begin{gathered}
\text { average no. of cells } \mathrm{x} \text { dilution } \\
\text { factor } \mathrm{x} 10^{4}
\end{gathered}
$$

\section{Determination of glucose and ethanol content} A total of $10 \mathrm{~mL}$ fermentation broth was withdrawn from the fermenter at every sampling hour. The sampled broth was centrifuged at $10,000 \mathrm{rpm}$ for 10 minutes. The resulting supernatant was used to determine the concentration of glucose and ethanol by high performance liquid chromatography (HPLC) (Shimadzu, Kyoto, Japan). The HPLC system is equipped with Shimadzu LC-20AT solvent delivery pump and Shimadzu RID-10A detector. The ethanol yield $\left(\mathrm{Y}_{\mathrm{E} / \mathrm{S}}\right)$ was calculated as the actual concentration of ethanol $(\mathrm{g})$ produced for every gram of glucose utilised. The volumetric ethanol productivity $\left(\mathrm{Q}_{\mathrm{p}}, \mathrm{g} / \mathrm{L} / \mathrm{h}\right)$ was calculated by dividing the concentration of ethanol produced by the time taken to reach the highest concentration of ethanol. In addition, the ethanol efficiency $\left(\mathrm{E}_{\mathrm{f}}\right)$ was calculated by finding the percentage of experimental ethanol yield divided by theoretical ethanol yield.

\section{Statistical method}

The data in this study were statistically analysed using SPSS software (SPSS Statistics Data Editor V.21, USA). T-test was used and the results were considered statistically significant if the $p$ value $<0.05$.

\section{RESULTS AND DISCUSSION}

\section{Cell growth}

Figure 1 shows the growth profile of $S$. cerevisiae cultivated in batch and fed-batch mode. The total cell count in the batch culture increased sharply from 0 to $6 \mathrm{~h}$ of fermentation and reached its maximum peak of $2.48 \times 10^{6}$ cells/ $\mathrm{mL}$ at $30 \mathrm{~h}$ before it decreased steadily towards the end of the fermentation. The final total cell number in the culture was $1.55 \times 10^{6}$ cells $/ \mathrm{mL}$. As depicted by Figure 1, the cell death in the batch culture was detected after $30 \mathrm{~h}$ of incubation. The relatively short survival period of the yeast cells can be associated with the high content of glucose in the batch medium that escalated the osmotic stress in yeasts, which consequently caused harmful effects on the yeast cells (Bafrncova, 1999).

In the fed-batch culture, the yeast growth increased steadily from 0 to $24 \mathrm{~h}$ of fermentation. 
There was a slight decline of yeast count at $30 \mathrm{~h}$, which was due to the feeding of fresh medium that caused the dilution of the culture. After $36 \mathrm{~h}$ of fermentation, the yeast count started to increase again and reached its maximum peak of $3.62 \times 10^{6}$ cells $/ \mathrm{mL}$ at $42 \mathrm{~h}$. The maximum yeast count achieved in fed-batch culture represents a 1.5-fold increment over that attained in the batch culture. Due to the feeding of the yeast cells at 24 $h$, the log phase of the cell growth in the fed-batch culture extended until $42 \mathrm{~h}$ in contrast to the batch culture where the growth declined at $30 \mathrm{~h}$. In this work, the incubation was stopped at $72 \mathrm{~h}$ due to the plateau production of ethanol despite the presence of viable cells in the culture. Prolonging the incubation time may not increase the ethanol production nor glucose consumption by the yeast cells.

Furthermore, it can be inferred that the toxic effect of the medium in the fed-batch culture was reduced since it was observed that the cell death occurred when the ethanol concentration reached
$80 \mathrm{~g} / \mathrm{L}$ at $42 \mathrm{~h}$. In contrast to the batch culture, the cell death took place at $30 \mathrm{~h}$ when the ethanol produced was $19 \mathrm{~g} / \mathrm{L}$. The cell death in the fedbatch fermentation might be due to the inhibitory effect of the high concentration of ethanol produced. Zhang et al. (2015) reported that the yeast growth completely stopped when the ethanol concentration exceeded $70 \mathrm{~g} / \mathrm{L}$. In contrast to the batch fermentation, the cell death may be contributed by the high concentration of glucose $(169 \mathrm{~g} / \mathrm{L})$ at $30 \mathrm{~h}$. The high concentration of glucose may introduce high osmotic pressure on the yeast cells and hence may lyse them. According to Stanbury et al. (1995), fed-batch fermentation can minimise substrate inhibition and toxic effects from the high concentration of the medium. In summary, the results presented in this work suggests that the fed-batch culture was more efficient in enhancing the yeast growth and in maintaining viable cells longer than in the batch culture.

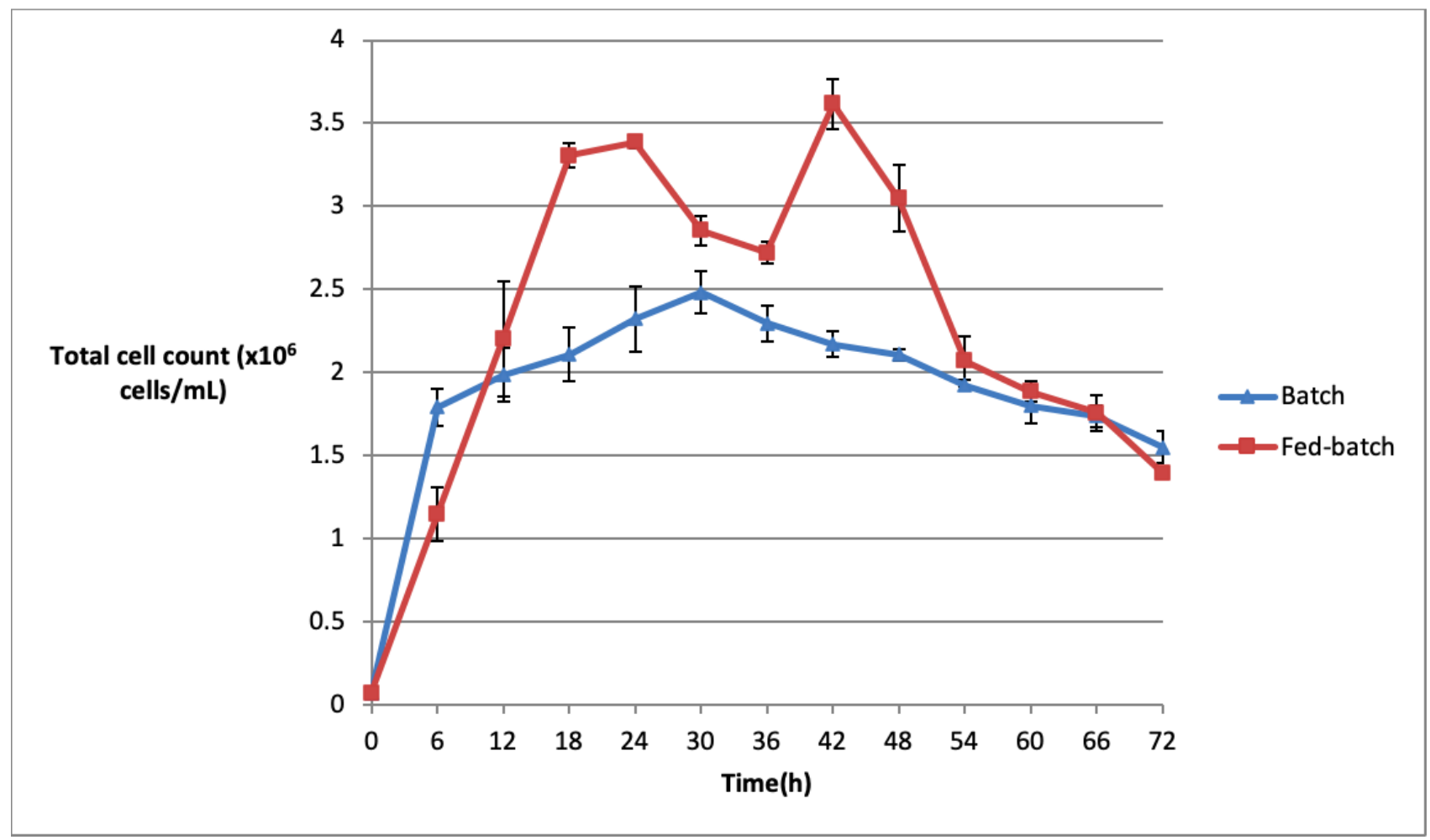

Figure 1. Total cell count of $S$. cerevisae in batch and fed-batch system within $72 \mathrm{~h}$ of fermentation.

\section{Glucose consumption}

The profile of glucose consumption in the batch and fed-batch cultures during the ethanol fermentation is illustrated in Figure 2. In the batch culture, there was a steady decrease of glucose concentration throughout the fermentation until the final concentration of 104 $\pm 6.0 \mathrm{~g} / \mathrm{L}$. On the other hand, in the fed-batch 
culture, the decrease of glucose concentration was observed in two phases namely from 0 to 30 $\mathrm{h}$ and from 36 to $72 \mathrm{~h}$. The spike of glucose concentration between 30 and $36 \mathrm{~h}$ was due to the feeding of the fresh medium. Despite the approximately similar concentration of glucose in the beginning of fermentation for both batch and fed-batch cultures, there was a difference in terms of the amount of glucose consumed. In the batch culture, the amount of glucose consumed by $S$. cerevisiae during the ethanol fermentation was $155 \pm 6.00 \mathrm{~g} / \mathrm{L}$. Meanwhile, in the fed-batch culture, about $224.71 \pm 0.86 \mathrm{~g} / \mathrm{L}$ of glucose was consumed making the consumption efficiency as $28 \%$ higher than that in the batch culture.

The low efficiency of glucose consumption by the yeast cells in the batch culture can be associated with the high osmotic pressure exerted on the whole yeast cells at the same time resulting in the decline of the cell growth at $30 \mathrm{~h}$.
In contrast, in the fed-batch culture, the twostage feeding of inoculum and medium was found to alleviate the impact of high osmotic pressure as what occurred in the batch culture. The remaining challenge in the fed-batch culture is to ensure complete glucose consumption by the end of the ethanol fermentation.

According to Bafrncova et al. (1999), supplementation of growth nutrients is crucial in order to ensure the optimal growth of $S$. cerevisiae and efficient consumption of the substrate supplied. This is parallel with some published works that reported the importance of growth supplements that help to improve sugar utilisation by S. cerevisiae (Ortiz-Muniz et al., 2010; Li et al., 2011; Sankh et al., 2011; Harde et al., 2014). The influence of growth supplements on the growth of $S$. cerevisiae during ethanol fermentation should be taken into consideration in the future work.

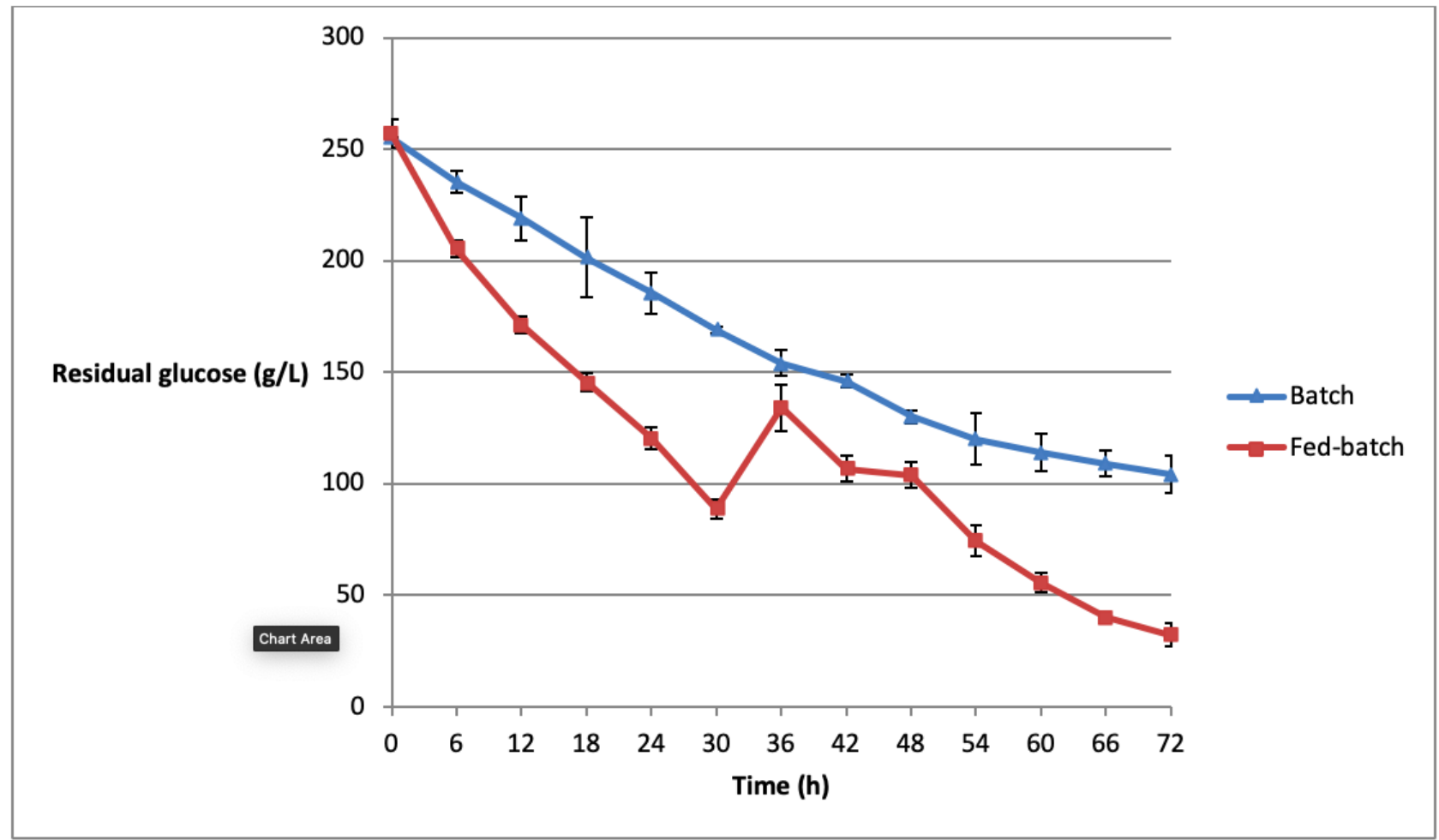

Figure 2. Residual glucose concentration in batch and fed-batch system during bioethanol fermentation.

\section{Ethanol production}

Figure 3 depicts the ethanol production by $S$. cerevisiae in batch and fed-batch fermentations. The highest ethanol produced in the fed-batch fermentation was $111.88 \pm 2.28 \mathrm{~g} / \mathrm{L}$ yielding an enhancement of 1.8 times higher than the maximum ethanol concentration achieved in the batch fermentation. The same increment was also seen in the ethanol productivity where $1.55 \mathrm{~g} / \mathrm{L}$ ethanol was produced per hour in the fed-batch culture in comparison to only $0.87 \mathrm{~g} / \mathrm{L}$ ethanol produced per hour in the batch culture. 
Meanwhile, the ethanol yield attained in the fedbatch culture represents an improvement of $22 \%$ over that achieved in the batch culture. The kinetic parameters of batch and fed-batch cultures are summarised in Table 1.

Our results for the ethanol yield in the fedbatch culture is parallel with what was reported by Khongsay et al. (2012) in which aeration was provided to the culture. In contrast, we managed to achieve the same yield without the use of aeration, which contributes an additional cost to the ethanol production. On the other hand, the ethanol yield achieved in the fed-batch culture in this study was found to be higher than that reported by Chen-Guang et al. (2012) in which VHG and redox potential-controlled conditions were applied. Similarly, the ethanol yield of the fed-batch culture in this study was higher than the value attained by Joannis-Cassan and co-workers (2014) where 3-stage fed-batch system was applied in the VHG ethanol fermentation. All the aforementioned works reported shorter fermentation time (53-56 h), which resulted in higher volumetric productivity $(2.07-2.55 \mathrm{~g} / \mathrm{L} / \mathrm{h})$. Despite longer fermentation time ( $72 \mathrm{~h}$ ) employed and lower $\mathrm{Q}_{\mathrm{p}}$ value attained in our study, the overall production cost was considered lower as there was no major modification of the fermenter involved. The fed-batch technique employed in this work involved manual addition of inoculum and fresh medium into the unaerated culture. Moreover, the strain used in this work was not genetically modified unlike those that were used in some works (Almeida et al., 2007; Liu, 2011; Ask et al., 2013; Wei et al., 2013). This clearly implies that the high ethanol productivity achieved in this work was contributed by the efficiency of the fed-batch technique employed.

Our study intended to provide a solution for sago millers to manage sago hampas, which is otherwise disposed as waste. On site valorisation of sago hampas for production of value-added products such as bioethanol may help the millers to generate more economic opportunities. The simple bioethanol fermentation technique as proposed in this work ranging from the yeast strain used, Baker's yeast that is available at the local market, to the simple fed-batch procedure, is seen as economically viable, which can be easily applied by sago millers. Future studies should focus on the effects of other essential parameters on the yeast growth and ethanol production such as $\mathrm{pH}$, oxygen, temperature, dissolved solids, organic acids and immobilization of yeast cells.

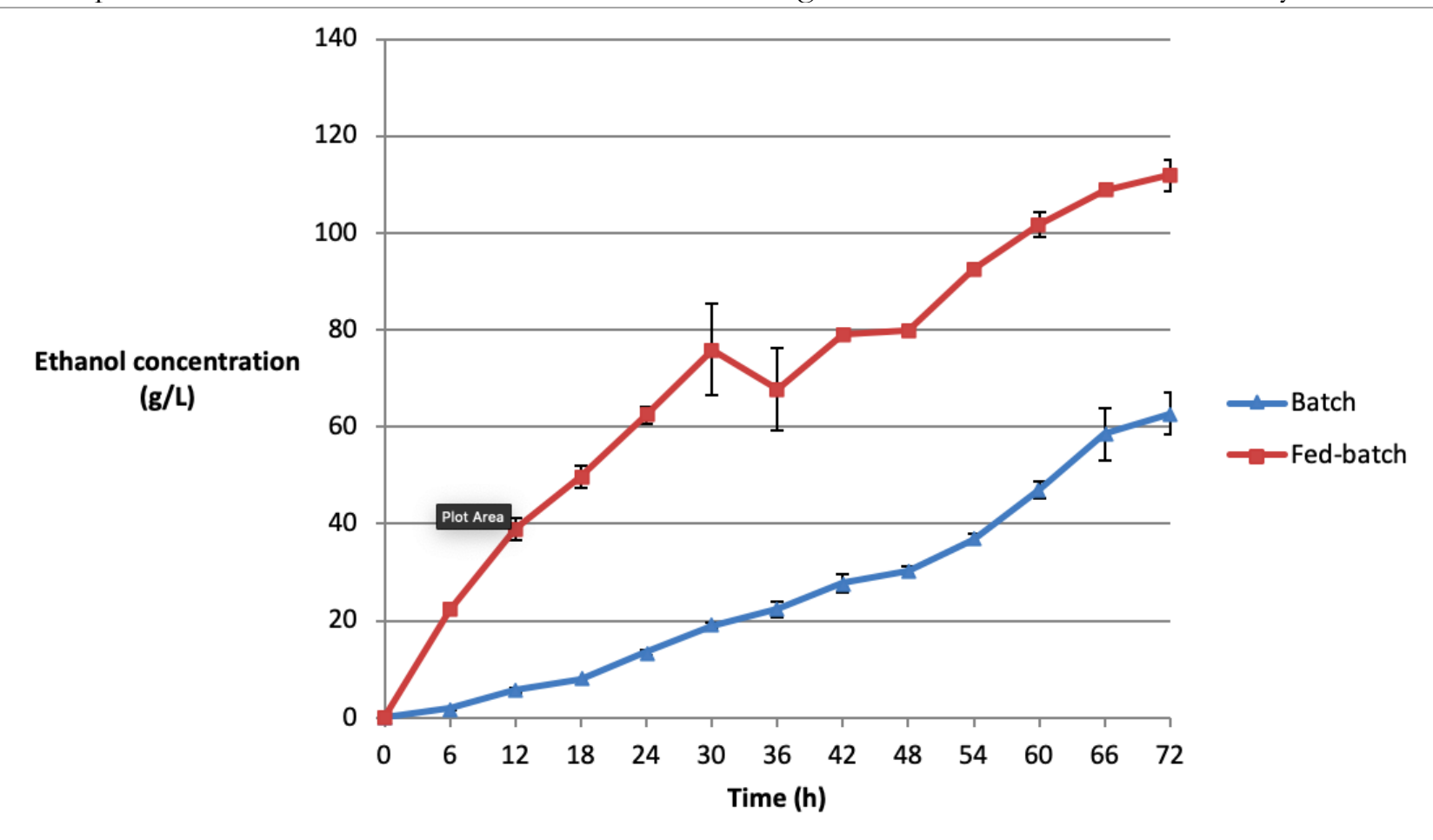

Figure 3. Profile of ethanol production by $S$. cerevisiae in batch and fed-batch fermentations. 
Table 1. Comparison of kinetic parameters between batch and fed-batch fermentations.

\begin{tabular}{lcc}
\hline Kinetic Parameters & Batch & Fed-batch \\
\hline Initial glucose $(\mathrm{g} / \mathrm{L})$ & $255.00 \pm 0.31$ & $256.91 \pm 4.59$ \\
Residual glucose $(\mathrm{g} / \mathrm{L})$ & $104.00 \pm 6.00$ & $32.19 \pm 3.73$ \\
Glucose consumption efficiency $(\%)$ & $59.22 \pm 2.35$ & $87.47 \pm 0.87$ \\
Ethanol produced, $\mathrm{P}_{\mathrm{E}}(\mathrm{g} / \mathrm{L})$ & $62.65 \pm 3.06$ & $111.88 \pm 2.28$ \\
$\mathrm{Q}_{\mathrm{p}}(\mathrm{g} / \mathrm{L} / \mathrm{h})$ & $0.87 \pm 0.06$ & $1.55 \pm 0.005$ \\
$\mathrm{Y}_{\mathrm{E} / \mathrm{s}}(\mathrm{g} / \mathrm{g})$ & $0.41 \pm 0.01$ & $0.5 \pm 0.004$ \\
$\mathrm{E}_{\mathrm{f}}(\%)$ & $80.23 \pm 2.35$ & $97.26 \pm 1.09$ \\
\hline
\end{tabular}

$\mathrm{Q}_{\mathrm{P}}=$ Volumetric ethanol productivity, $\mathrm{Y}_{\mathrm{E} / \mathrm{s}}=$ Ethanol yield, $\mathrm{E}_{\mathrm{f}}=$ Ethanol efficiency

\section{CONCLUSION}

This work has demonstrated the feasibility of fedbatch fermentation to enhance the VHG bioethanol production using $\mathrm{SHH}$ as a main substrate. Our results showed that the $S$. cerevisiae growth was significantly higher in the fed-batch culture than in the batch culture. The maximum yeast cell concentration achieved in the fed-batch fermentation was 1.5 -fold higher than that achieved in the batch fermentation. The glucose consumption efficiency was also significantly improved in the fed-batch fermentation. Moreover, the ethanol yield was significantly enhanced by $22 \%$ when the fermentation was carried out in the fed-batch mode. The ethanol productivity achieved in the fed-batch culture was 1.8 times higher than that achieved in the batch culture. It can be concluded that the fed-batch fermentation technique as proposed in this work can serve as a promising approach for enhancing the production of VHG bioethanol from sago hampas, which is known as a low cost and sustainable fermentation feedstock.

\section{ACKNOWLEDGEMENTS}

This research was supported by Fundamental Research Grant Scheme (F07/FRGS/1616/ 2017) from Ministry of Education (MOE) Malaysia. We would like to acknowledge Ubom Sago Sdn. Bhd. and Herdsen Sago Industry Sdn. Bhd. for providing sago hampas.
Almeida, J. R. M., Modig, T., Petersson, A., Hahn-Hägerdal, B., Lidén, G., \& Gorwa-Grauslund M. F. 2007. Increased tolerance and conversion of inhibitors in lignocellulosic hydrolysates by Saccharomyces cerevisiae. Journal of Chemical Technology \& Biotechnology 82(4): 340-349.

Ask, M., Mapelli, V., Höck, H., Olsson, L., \& Bettiga M. 2013. Engineering glutathione biosynthesis of Saccharomyces cerevisiae increases robustness to inhibitors in pretreated lignocellulosic materials. Microbial Cell Factories 12: 87.

Awg-Adeni, D. S. 2015. Bioethanol production from residual starch of sago (Metroxylon sagu Rottb.) hampas. Thesis Doctor of Philosophy. Faculty of Biotechnology and Biomolecular Sciences. Universiti Putra Malaysia, Serdang, Malaysia.

Awg-Adeni, D. S., Bujang, K. B., Hassan, M. A., \& Abd-Aziz, S. 2013. Recovery of glucose from residual starch of sago hampas for bioethanol production. Journal of Biomedical Research International 8: 2013-2021. Article ID 935852.

Awg-Adeni, D. S., Abd-Aziz, S., Bujang, K. B., \& Hassan, M. A. 2010. Bioconversion of sago residue into value-added products. African Journal of Biotechnology 9(14): 2016-21.

Bafrncova, P., Smogrovicova, D., Slavikova, I., Patkova, J. \& Domeny, Z. 1999. Improvement of very high gravity ethanol fermentation by media supplementation using Saccharomyces cerevisiae. Biotechnology Letters 21: 337-341.

Bujang, K. B., Apun, K., \& Salleh, M. A. 1996. A study in the production and bioconversion of sago waste. In: Proceeding 6th International Sago Symposium Sago: The Future Source of Food and Feed. Eds. Jose, C. and Rasyad, R. pp: 193-200. Universitas Riau, Pekan Baru, Sumatra. Republic of Indonesia.

Chen-Guang, L., Na W., Yen-Han, L., \& Feng-Wu, B. 2012. Very high gravity ethanol fermentation by flocculating yeast under redox potential-controlled conditions. Biotechnology and Biofuels 5(1): 61.

Dodic, S., Popov, S., Dodic, J., Rankovic, J., Zavargo, Z., \& Mucibabic, R. J. 2009. Bioethanol production from thick juice as intermediate of sugar beet processing. Biomass \& Bioenergy 33(5): 822-827.

Gutierrez'-Rivera, B., Waliszewski-Kubiak, K., Carvajal-Zarrabal, O., \& Aguilar-Uscanga, M. G. 2012. Conversion efficiency of glucose/xylose mixtures for ethanol production using Saccharomyces cerevisiae ITV01 and Pichia stipitis NRRL Y7124. Journal of Chemical Technology and Biotechnology 87(2): 263-270.

Harde, S. M., Bankar, S. B., Ojamo, H., Granstrom, T., Singhal, R. S., \& Survase, S. A. 2014. Continuous lignocellulosic ethanol production using Coleus forskoblii root hydrolysate. Fuel 126: 77-84. 
Ingledew, W. \& Lin, Y-H. 2011. Biofuels and bioenergy - ethanol from starch-based feedstocks. In: Comprehensive Biotechnology. Ed. Moo-Young M. pp. 37-49. Elsevier.

Ishola, M. M., \& Taherzadeh, M. J. 2014. Effect of fungal and phosphoric acid pretreatment on ethanol production from oil palm empty fruit bunches (OPEFB). Bioresource Technolog) 165: 9-12

Janggu, U., \& Bujang, K. B. 2009. Maximizing sugar production from enzymatic hydrolysis of sago fibre for ethanol fermentation.1 $1^{\text {st }}$ ASEAN Sago Symposium. Riverside Majestic Hotel, Kuching. 29-30 th October, 2009.

Jenol, M. A., Ibrahim, M. F., Yee, P. L., Md Salleh, M., \& AbdAziz, S. 2014. Sago biomass as a sustainable source for biohydrogen production by Clostridium butyricum A1. Bioresources 9(1): 1007-1026.

Joannis-Cassan, C., Riess, J., Jolibert, F., \& Taillandier, P. 2014. Optimization of very high gravity fermentation process for ethanol production from industrial sugar beet syrup. Biomass and Bioenergy 70: 165-173.

Khongsay, N., Laopaiboon, L., Jaisil, P., \& Laopaiboon, P. 2012. Optimization of agitation and aeration for very high gravity ethanol fermentation from sweet sorghum juice by Saccharomyces cerevisiae using an orthogonal array design. Energies 5: 561-576.

Li, Y., Gao, K., Tian, S., Zhang, S., \& Yang, X. 2011. Evaluation of Saccharomyces cerevisiae Y5 for ethanol production from enzymatic hydrolysate of non-detoxified steam-exploded corn stover. Bioresource Technology 102(22): 10548-10552.

Linggang, S., Phang, L. Y., Wasoh, M. H., \& Abd-Aziz, S. 2012. Sago pith residue as an alternative cheap substrate for fermentable sugars production. Applied Biochemistry and Biotechnology 167: 122-31.

Liu, Z. L. 2011. Molecular mechanisms of yeast tolerance and in situ detoxification of lignocellulose hydrolysates. Applied Microbiology and Biotechnology 90(3): 809-25.

Mohammad, S., Awg-Adeni, D. S., Bujang, K. B., Vincent, M., \& Baidurah, S. 2020. Potentials of sago fibre hydrolysate $(\mathrm{SFH})$ as a sole fermentation media for bioethanol production. IOP Conference Series: Materials Science and Engineering 716(2020).

Ortiz-Muniz, B., Carvajal-Zarrabal, O., Torrestiana-Sanchez, B., \& Aguilar-Uscanga, M. G. 2010. Kinetic study on ethanol production using Saccharomyces cerevisiae ITV-01 yeast isolated from sugar canemolasses. Journal of Chemical Technology and Biotechnology 85(10): 1361-1367.

Phukoetphim, N., Salakkam, A., Laopaiboon, P., \& Laopaiboon, L. 2017. Improvement of ethanol production from sweet sorghum juice under batch and fed-batch fermentations: Effects of sugar levels, nitrogen supplementation, and feeding regimes. Electronic Journal of Biotechnology 26(2017): 84-92.

Puligundla, P., Smogrovicova, D., Obulam, V. S. R., \& Ko, S. 2011. Very high gravity (VHG) ethanolic brewing and fermentation. Journal of Industrial Microbiology and Biotechnology 38: 1133-1144.

Sankh, S. N., Deshpande, P. S., \& Arvindekar, A. U. 2011. Improvement of ethanol production using Saccharomyces cerevisiae by enhancement of biomass and nutrient supplementation. Applied Biochemistry and Biotechnology 164(8): $1237-1245$.

Stanbury, P. F., Whitaker, A., \& Hall, S. J. 1995. Principles of fermentation technology. Oxford: ButterworthHeinemann.

Vincent, M., Senawi, B. R., Esut, E., Muhammad Nor N., \& AwgAdeni, D. S. 2015. Sequential saccharification and simultaneous fermentation (SSSF) of sago hampas for the production of bioethanol. Sains Malaysiana 44(6): 899-904.
Wei, N., Quarterman, J., Kim, S. R., Cate, J. H. D., \& Jin, Y-S. 2013. Enhanced biofuel production through coupled acetic acid and xylose consumption by engineered yeast. Nature Communications 4: 2580.

Zhang, Q., Wu, D., Lin, Y., Wang, X., Kong, H., \& Tanaka, S. 2015. Substrate and product inhibition on yeast performance in ethanol fermentation. Energy Fuel 29: 1019_ 27. 